\title{
Culture and Context: Challenges to the Implementation of English Language Curricula in Asia
}

\author{
Richmond Stroupe, Editor-in-Chief \\ Soka University, Japan
}

In the 1990s, the cultural appropriacy of the communicative approach in English as a Foreign and Second Language (EFL / ESL) instruction in Asia was being questioned (Ellis, 1996). Even then, researchers were discussing the cultural conflict which could possibly occur in the language learning environment between western native-speaking English instructors, who naturally brought with them their preconceptions of an educational context based on their cultural experiences, and their students, who had studied within and been influenced by different cultural traditions. This discussion continues, but while the focus in the past was on the duality of western teachers working with Asian learners, today the landscape of English language instruction in Asia is far more complex, representing a myriad of stakeholders, motivational underpinnings, and national education policies (Chen, Warden, \& Chang, 2005; Kam, 2002; Littlewood, 2007; Tan, 2005; Warden \& Lin, 2000).

The growing importance of English globally has been well documented in general, and in Asia in particular (Graddol, 1997, 2006; Kam, 2002; Nunan, 2003; Phillipson, 2001; Su, 2006; Stroupe, 2010, Suarez, 2005). Driven by the globalization of economic development (Stroupe \& Panda, 2007; Su, 2006), international tourism (Graddol, 2006), regional and international organizations, and military relationships (Phillipson, 2001), English language education remains a main avenue for economic opportunity, international exchange, and progress in developing countries (Graddol, 2006).

In response to these regional developments, national policies have increased emphasis on English language instruction at multiple levels of local educational systems. The impact resulting from these initiatives has been dynamic (Kam, 2002; Kim, 2004; Kirkpatrick, 2010; D. Li, 1998; Nunan, 2003; Su, 2006). While traditionally introduced at the upper secondary and tertiary levels, increasingly, English language instruction is being implemented at lower secondary and primary levels, and in some cases at the pre-primary level (Graddol, 2006; Kam, 2002; Kirkpatrick, 2010; Suarez, 2005).

This phenomenon results in far-reaching effects in the region. Considering an approximate eight-year period necessary to achieve academic proficiency, the age at which students will reach this goal is decreasing from a post-graduation target when language study is begun at the tertiary level to a secondary level target when young learners begin their English study at primary or pre-primary levels. As a result, the numbers of English language learners at the

Language Education in Asia, 2012, 3(2), 126-131. http://dx.doi.org/10.5746/LEiA/12/V3/I2/A01/Stroupe 
tertiary level are projected to actually decrease over the next 20 years as more and more students achieve fluency prior to entering university (Graddol, 2006). In addition, English proficiency is increasingly seen as a basic skill and less as a competitive advantage, yet much more of a handicap if learners do not reach expected proficiency levels (Graddol, 2006). At the same time, local varieties of English are becoming more accepted, with less emphasis being placed on native-like proficiency as a learning outcome and more emphasis placed on communicative ability. The value and role of non-native English speaking instructors is changing accordingly (Graddol, 2006; Higgins, 2003; Liu, 1999; Milambiling, 2000; Tomlinson, 2005; Warschauer, 2000).

Yet the growth of English language instruction in the Asian region has not been without controversy and challenge (Kam, 2002; Kirkpatrick, 2010; Nunan, 2003). Oftentimes, the exam-driven curriculum and large classes with mixed level or under-motivated students are indicated as major challenges to the implementation of communicative methodologies in English language classrooms in Asia (Gray, 1998; Kam, 2002; Littlewood, 2007; Su, 2006). Indeed, the motivation of students may be quite different in a learning context where the practical use of English is to achieve necessary test results for university admission or employment opportunities rather than learning about and engaging with those from Englishdominant cultures (Chen, Warden, \& Chang, 2005; Warden \& Lin, 2000).

Another area of concern is the number of teachers necessary at different levels within the educational systems in the region to implement the language learning policies of local governments. An illustrative example is China, where the potential implementation of a broad language learning curricula could result in a demand for hundreds of thousands of English teachers (Liao, 2004). At the same time, there are concerns over the proficiency and skill levels of prospective teachers at a time when local governments and international organizations may be struggling with meeting this increased demand for qualified instructors (Kam, 2002; Kim, 2004; Nunan, 2003; Simpson, 2008).

Furthermore, in an environment where there is high demand for skilled teachers, there may be a resulting exacerbation of existing socioeconomic and regional (urban and rural) disparities, as qualified teachers are often attracted to higher salaried positions at urban schools, leaving teachers in lower socioeconomic or rural areas to rely on more traditional approaches to language instruction with limited resources (Hu, 2005; Kam, 2002).

How local cultures interact with English language instruction also continues to be a focus of discussion and research in the region. The passivity of Asian students is often highlighted as a cultural barrier to successful communicative language instruction. However, other researchers suggest that this constraint is over-generalized and may not be a result of cultural factors, but rather due to inappropriate methodologies employed by teachers or learners' lack of sufficient proficiency (Cheng, 2000). Culture also affects learning styles (Goodson, 1993; Rao, 2002), views on testing, expectations of both students and teachers, and perceptions of the overall learning process (Gray, 1998; Hu, 2002; Kim, 2004; M. Li, 2003; Simpson, 2008; Tan, 2005). Most authors suggest mediating these cultural differences by striking an appropriate balance between more western-oriented communicative approaches and more familiar, local, traditional approaches to language learning (Ellis, 1996; Lewis \& McCook, 2002; Simpson, 2008; Tan, 2005; Tomlinson, 2005).

The papers included in the current issue of Language Education in Asia strive to continue to contribute to the discussion and research on the challenges and successes related to English language learning curricula implemented in the region. The first two papers report findings 
from research investigations in East and Southeast Asia. Kiyomi Chujo, Laurence Anthony, Kathryn Oghigan, and Asako Uchibori investigated a data driven learning approach using a parallel corpus for beginning English language learners in Japan. Their findings indicate that the students in the study made significant gains in their understanding of grammatical structures based on this approach. A second research paper considers the utility of using video recordings to help students develop their presentation skills. Kulawadee Yamkate and Charatdao Intratat found that the use of video allowed university students in Thailand to improve their selfevaluation skills, leading to enhanced performance during their presentations.

A number of papers in this issue examine innovative methodologies to enhance language learning. Colin Thompson and Neil Millington focus on task-based learning, implementing this approach in Japan in larger classes typical in the Asian context. Project work is the focus of a paper by Nicholas Marshall, who indicates that the use of such collaborative activities provides students with the opportunity to develop interactional competence and makes suggestions as to how this approach can be adapted to the Asian context. Jason Hendryx discusses how a variety of student groupings can be utilized in the language learning classroom. Here, the author presents how the use of diverse student groupings can lead to variety within lessons and increased interest on the part of students. Developing greater understanding of academic texts is the focus of a paper by Mikiko Sudo and Asako Takaesu. Through presenting concept maps based on texts, students in Japan have been able to achieve a greater level of reading comprehension through collaborating with their peers.

Technology is emphasized by Jon Watkins. Through a combination of videoing and blogging, Watkins' students were able to increase the time in which they used English outside the classroom, while at the same time more effectively and efficiently provide and receive feedback. The use of technology to achieve a "paperless" classroom is the topic of a paper by Kelly Butler and Michael Wilkins. Based on an investigation at a university in Japan, these two authors provide explanations on how available programs and technology can be employed to increase the efficiency of the learning process.

Across the Asian region, local teachers must often work with required materials and texts selected by institutional or national administrators. In Cambodia, Chea Kagnarith, Alan Klein, and John Middlecamp provide practical guidelines and encourage local teachers to adapt their required materials to better suit the interests and needs of their students. In Japan, Paul Mennim suggests ways that students can actually create materials used in class. With the appropriate scaffolding and support, the students on which this paper is based were able to generate their own materials and teach a portion of their class.

The final two teaching practice papers in this issue consider specific needs of students. Learning strategies are the focus of a paper by Douglas Meyer. A comparison of typical western language learning strategies and those commonly found in Asia is presented. Then, a number of specific strategies which could be explicitly taught in the language learning classroom are discussed. Lastly, Darrell Wilkinson presents ways in which motivation can be increased with students in relation to intensive and extensive reading. Based on an action research project conducted with university-level students in Japan, recommendations are made on how to increase the student-centered focus during reading activities.

The medium of instruction, whether L1 or L2, has long been an issue which elicits passionate debate. Le Duc Manh critically analyzes the implementation of English medium of instruction classes at a Vietnamese university. In his commentary, Manh suggests that the use of English as 
a medium of instruction, while challenging, is timely and appropriate in this age of increasing globalization.

The development of an academic publication is a collaborative effort, involving many professionals, volunteers and specialists, all working in concert to produce a relevant and applicable addition to the body of knowledge within our field. Under the direction of the publication's Advisory Board, the members of the Editorial Board strive to provide a space for authors in the Asian region to share their experiences, successes, and research findings to a wider audience. It is our contributing authors, and their willingness to share their ideas and research, that make the development of this online publication possible. In collaboration with the Assistant Editors, the Assistant Editor-in-Chief, Kelly Kimura, contributes significantly in many ways to bring each issue to fruition. It is with great appreciation that I extend heartfelt appreciation to the Assistant Editor-in-Chief, and to all of the members of the Advisory and Editorial Boards for their untiring support and commitment to the Language Education in Asia publication.

While authors may disagree on the most appropriate method to utilize in a particular context, or on how cultural differences can be best reconciled, most do agree on the growing importance of English language education in Asia. Challenges will continue to be faced, and innovative approaches will continue to be developed as more and younger language learners begin their study of English. In response, researchers and practitioners in the region and beyond will continue to investigate and improve their instruction, and as a result, the outcomes of their learners. The role of the Language Education in Asia publication is, and will continue to be, to provide opportunities to professionals in the region to exchange these ideas, and share expertise, experiences, and advice. 


\section{References}

Chen, J. F., Warden, C. A., \& Chang, H. (2005). Motivators that do not motivate: The case of Chinese EFL learners and the influence of culture on motivation. TESOL Quarterly, 39(4), 609-633. http://dx.doi.org/10.2307/3588524

Cheng, X. (2000). Asian students' reticence revisited. System, 28 (3), 435-446. http://dx.doi.org/10.1016/S0346-251X(00)00015-4

Ellis, G. (1996). How culturally appropriate is the communicative approach? ELT Journal, 50(3), 213-218. http://dx.doi.org/10.1093/elt/50.3.213

Goodson, T. J. (1993). Learning style preferences of East Asian ESL students. (Doctoral dissertation). Retrieved from http://trace.tennessee.edu/utk_graddiss/1254

Graddol, D. (1997). The future of English? London, England: British Council.

Graddol, D. (2006). English next. London, England: British Council.

Gray, R. (1998, October 16 - 18). Confucian conundrums: Higher education and ESL teaching in Korea and Japan. In Korea TESOL (Ed.), Proceedings of the 1998 Korea TESOL Conference. Paper presented at the 1998 Korea TESOL Conference, Kyunghee University, Seoul, South Korea (pp. 45-50). Seoul, South Korea: KOTESOL.

Higgins, C. (2003). "Ownership" of English in the outer circle: An alternative to the NS-NNS dichotomy. TESOL Quarterly, 374), 615-644. http://dx.doi.org/10.2307/3588215

$\mathrm{Hu}, \mathrm{G}$. (2002). Potential cultural resistance to pedagogical imports: The case of Communicative Language Teaching in China. Language, Culture and Curriculum, 15(2), 93-105. http://dx.doi.org/10.1080/07908310208666636

$\mathrm{Hu}, \mathrm{G}$. (2005). Contextual influences on instructional practices: A Chinese case for an ecological approach to ELT. TESOL Quarterly, 39(4), 635-660. http://dx.doi.org/10.2307/3588525

Kam, W. H. (2002). English language teaching in East Asia today: An overview. Asia-Pacific Journal of Education, 22(2), 1-22. http://dx.doi.org/10.1080/0218879020220203

Kim, S. J. (2004). Coping with cultural obstacles to speaking English in the Korean Secondary School context. Asian EFL Journal, September 2004. Retrieved from http://www.asianefl-journal.com/september_04_ksj.php

Kirkpatrick, A. (2010). Learning English in ASEAN: Myths and principles. Language Education in Asia, 1(1), 1-7. http://dx.doi.org/10.5746/LEiA/10/V1/A02/Kirkpatrick

Lewis, M., \& McCook, F. (2002). Cultures of teaching: Voices from Vietnam. ELT Journal, 56(2), 146-153. http://dx.doi.org/10.1093/elt/56.2.146

$\mathrm{Li}, \mathrm{D}$. (1998). "It's always more difficult than you plan and imagine": Teachers' perceived difficulties in introducing the Communicative Approach in South Korea. TESOL Quarterly, 32(4), 677-703. http://dx.doi.org/10.2307/3588000

Li, M. (2003, November 29-December 3). Culture and classroom communication: A case study of Asian students in New Zealand language schools. Paper presented at the joint NZARE-AARE Conference 2003 at University of Auckland, New Zealand. Auckland, New Zealand: NZARE-AARE.

Liao, X. (2004). The need for Communicative Language Teaching in China. ELT Journal, 58(3), 270-273. http://dx.doi.org/10.1093/elt/58.3.270

Littlewood, W. (2007). Communicative and task-based language teaching in East Asian classrooms. Language Teaching, 40(3), 243-249. http://dx.doi.org/10.1017/S0261444807004363

Liu, J. (1999). Nonnative-English-speaking professionals in TESOL. TESOL Quarterly, 33(1), 85102. http://dx.doi.org/10.2307/3588192

Milambiling, J. (2000). Comments on Vivian Cook's "Going beyond the native speaker in language teaching: How nonnative speakers as teachers fit into the equation." TESOL Quarterly, 34(2), 324-328. http://dx.doi.org/10.2307/3587955 
Nunan, D. (2003). The impact of English as a global language on educational policies and practices in the Asia-Pacific region. TESOL Quarterly, 374), 589-613. http://dx.doi.org/10.2307/3588214

Phillipson, R. (2001). English for globalization or for the world's people? International Review of Education, 4オ3/4), 185-200. http://dx.doi.org/10.1023/A:1017937322957

Rao, Z. (2002). Bridging the gap between teaching and learning styles in East Asian contexts. TESOL Journal, 11(2), 5-11.

Simpson, S. T. (2008). Western EFL teachers and East-West classroom-culture conflicts. RELC Journal, 39(3) 381-394. http://dx.doi.org/10.1177/0033688208096847

Stroupe, R. (2010). The complexity and challenge of language education in Asia. Language Education in Asia, 1(1), iii-vii. http://dx.doi.org/10.5746/LEiA/10/V1/A01/Stroupe

Stroupe, R. \& Panda, I. (2007, January). A framework for facilitating the teaching of culture in the EFL classroom. Paper presented at the 27 th International Thailand TESOL Conference and 10th Pan-Asian Consortium International Conference 2007 in Bangkok, Thailand.

Su, Y. (2006). EFL teachers' perceptions of English language policy at the elementary level in Taiwan. Educational Studies, 32(3), 265-283. http://dx.doi.org/10.1080/03055690600631218

Suarez, S. L. (2005). Does English rule? Language instruction and economic strategies in Singapore, Ireland and Puerto Rico. Comparative Politics, 374), 459-478.

Tan, C. (2005). How culturally appropriate is the communicative approach for primary school children in Singapore? The Reading Matrix, 5(1), 21-35.

Tomlinson, B. (2005). The future for ELT materials in Asia. Electronic Journal of Foreign Language Teaching, 2(2), 5-13. Retrieved from http://eflt.nus.edu.sg/v2n22005/tomlinson.pdf

Warden, C. A., \& Lin, H. J. (2000). Existence of integrative motivation in an Asian EFL setting. Foreign Language Annals, 33(5), 535-545. http://dx.doi.org/10.1111/j.19449720.2000.tb01997.x

Warschauer, M. (2000). The changing global economy and the future of English teaching. TESOL Quarterly, 34(3), 511-535. http://dx.doi.org/10.2307/3587741 